\title{
Validation of Korean Meat Products and Processed Cheese for the Detection of GMO using p35S and tNOS Primers
}

\author{
Hyo-Jin Shin, Eun-Jeong Heo, Jin-San Moon, Ji-Ho Kim, Young-Jo Kim, \\ Hyun-Jung Park, Yo-Han Yoon ${ }^{1}$, Jin-Man Kim², and Sung-Hwan Wee* \\ Division of Livestock Product Standard, Animal, Plant and Fisheries Quarantine and Inspection Agency, \\ Anyang 430-824, Korea \\ ${ }^{1}$ Department of Food and Nutrition, Sookmyung Women's University, Seoul 140-742, Korea \\ ${ }^{2}$ Department of Food Science and Biotechnology of Animal Resources, Konkuk University, Seoul 143-701, Korea
}

\begin{abstract}
In this study, 543 samples of press hams, sausages, processed ground meat and processed cheese acquired from retail markets in Seoul and Gyeonggi province in Korea from 2005 to 2010 were monitored using a one-step multiplex polymerase chain reaction (PCR) method that involves the amplification of specific soya or maize endogenous genes and the amplification of 35S promoter (p35S) and nopaline synthase terminator (tNOS) for GMO detection. Among the 543 samples, 477 samples were amplified for maize and/or soybean endogenous genes. Although one sausage sample collected in 2008 showed amplification of tNOS, the result was assumed to be false positive based on the results from further tests of other sausage samples of the same brand. Our results demonstrate the absence of GM soya and/or maze of livestock products in the Korean market during 2005-2010. In addition, the one-step multiplex PCR using previously constructed primer sets appears to be useful as a screening method for the detection of GMOs in processed livestock products. However, more specific methods should be established and employed to detect the event-specific GM gene for positive reaction samples by screening tests in processed livestock products.
\end{abstract}

Key words: livestock products, genetically modified maize, genetically modified soybean, multiplex polymerase chain reaction (PCR)

\section{Introduction}

Genetic modification technology has enabled the development of a variety of genetically modified (GM) crops, and many countries have authorized the commercialization of GM food and feed (Hurst et al., 1999; Lee et al., 2004b). As consumer concern over the safety of GM foods has grown, many countries have established labeling systems based on their own criteria, with the threshold for the intentional mixing level of GM crops as $0.9 \%$ in the European Union and 5 in Japan (Food and Marketing Bureau, 2000; Regulation, 2003). The consumption of soybean and maize in Korea relies almost entirely on imports, because of low-self-sufficiency rate of these crops in Korea (about $7.3 \%$ and $0.8 \%$, respectively) (Kim

*Corresponding author: Sung-Hwan Wee, Division of Livestock Product Standard, Animal, Plant and Fisheries Quarantine and Inspection Agency, Anyang 430-824, Korea. Tel: 82-31-4671990, Fax: 82-31-467-4330, E-mail: wsh2010@korea.kr et al., 2006; KOSIS, 2005). In 2001, Korea formally enforced labeling for foods containing $>3 \%$ GM maize, soybean seeds and soybean sprouts (KFDA, 2000; Lee et al., 2004b; MAF, 2000; Phillips and McNeill, 2000). Soybean and maize imported to Korea presumably includes GM products (Hwang et al., 2003a; Lee et al., 2004a, 2004b). This has implications for other domestic food, since maize starch and soybean are often added as flavor enhancers to processed meat and dairy products such as press ham, sausage, processed ground meat and milk products (Hwang et al., 2003a; Lee et al., 2004a, 2004b).

A number of methods have been developed for the detection of genetically modified organisms (GMOs) from food stuffs. Recently, the presence of GMOs in food stuffs is commonly determined by PCR methods which is specific and sensitive to detect even very low concentration of specific organism DNAs (Forte et al., 2005; Gachet et al., 1998; Holst-Jensen et al., 2003; Hurst et al., 1999; Lin et al., 2001; Matsuoka et al., 2001; Meyer, 1995, 1996; Rho et al., 2004; Tengel et al., 2001). 
In Korea, GM genes have been examined for monitoring GM soybean and maize in many sampling sites (Hwang et al., 2003b; Kim et al., 2006). Adding 5-10\% or less of starch is allowed in Korean processed press hams and sausages therefore, it is necessary to monitor whether GMO is mixed in these products. For monitoring GM genes in meat products, polymerase chain reaction (PCR) assays were developed for GM maize and GM soybean (Chung et al., 2004). However, no data are available on the detection of GMOs in processed meat and dairy products using PCR for screening. Therefore, the present study focused on the one-step multiplex PCR detection of GMOs in processed meat and dairy foods formulated with maize starch and soybean, which were purchased from retail markets in Seoul and Gyeonggi province during 2005-2010.

\section{Materials and Methods}

\section{Samples and reference materials}

A total of 543 processed meat and dairy foods formulated with soybeans and maize starch were randomly purchased from supermarkets in Seoul and Gyeonggi province in Korea from 2005 to 2010. The samples were sorted into processed meat products such as sausages, press hams and ground meat products, and dairy products such as processed cheese (Table 1). The certified reference materials used as the positive control consisted of corn and soybean that were positive for GM DNA (Nexgen Biotechnology, Korea).

\section{DNA extraction}

Samples were cut into small pieces with scissors, and DNA isolation was carried out using a Powerprep DNA extraction kit (Kogene, Korea) according to the manufacturer's procedure. Briefly, 1-2 g portions of samples were added to $15-\mathrm{mL}$ conical tubes, followed by $4 \mathrm{~mL}$ of lysis buffer A and $300 \mu \mathrm{L}$ of lysis buffer B. After incubation at $37^{\circ} \mathrm{C}$ for $1 \mathrm{~h}, 4 \mathrm{~mL}$ of $97 \%$ chloroform was added and tubes were vortexed for $15 \mathrm{~s}$ followed by centrifugation at 2,400 g for $15 \mathrm{~min}$. Each supernatant was transferred to an Eppendorf tube and $1 \mathrm{~mL}$ of chloroform was added. After vigorous vortexing, the tube was centrifuged at 2,400 $\mathrm{g}$ for $10 \mathrm{~min}$ at room temperature and the obtained supernatant was added to a clean Eppendorf tube containing $1.2 \mathrm{~mL}$ of binding buffer. After vortexing, $700 \mu \mathrm{L}$ of the mixture was transferred to a QIAamp spin column tube (Qiagen, USA) contained in a $1.2 \mathrm{~mL}$ collection tube and centrifuged at $8,000 \mathrm{~g}$ for $1 \mathrm{~min}$. Each column tube was then placed in a new clean $1.2 \mathrm{~mL}$ collection tube. This step was repeated twice. Seven hundred microliters of $75 \%$ ethanol was added to each column tube and centrifuged at 8,000 $\mathrm{g}$ for $1 \mathrm{~min}$. This step was also repeated twice. Each column was centrifuged at $8,000 \mathrm{~g}$ for $3 \mathrm{~min}$ to discard the remainder of the ethanol and transferred to a clean Eppendorf tube followed by addition of $120 \mu \mathrm{L}$ of DNase-free water (Invitrogen, USA). The tubes were incubated at room temperature for 15-20 min and centrifuged at $6,000 \mathrm{~g}$ for $5 \mathrm{~min}$. The concentration of extracted DNA was measured by a nanophotometer (Implen, Germany).

\section{Multiplex PCR}

The sequences of nucleotide primers are shown in Table 2. The CaMV 35S (p35S) and nopaline synthetase terminator (tNOS) primer pairs were previously reported by Kuribara et al. (2002). The lectin gene and zein gene primer set amplified endogenous gene of soybean and maize, respectively, were previously reported (Chung et al., 2004). All primers were synthesized by Bioneer (Korea). PCR was carried out in T personal thermocycler system (Biometra, Germany) using a $20 \mu \mathrm{L}$ reaction volume with $2 \times$ ready dispensed mix (Kisanbiotech, Korea) in $8 \mu \mathrm{L}$ PCR tubes, $1 \mu \mathrm{L}$ of each four pairs of primers with $0.2 \mu \mathrm{M}$ and $12 \mu \mathrm{L}$ template. The PCR conditions were $95^{\circ} \mathrm{C}$ for $10 \mathrm{~min}$, and 40 cycles of $95^{\circ} \mathrm{C}$ for $30 \mathrm{~s}, 60^{\circ} \mathrm{C}$ for $30 \mathrm{~s}, 72^{\circ} \mathrm{C}$ for $30 \mathrm{~s}$, and $72^{\circ} \mathrm{C}$ for $7 \mathrm{~min}$. Amplified DNAs were analyzed by electrophoresis on a $0.2 \%$ agarose gel

Table 1. Processed meat and dairy products collected from Korean supermarkets during 2005 to 2010

\begin{tabular}{|c|c|c|c|c|c|c|c|}
\hline Products & 2005 & 2006 & 2007 & 2008 & 2009 & 2010 & Total \\
\hline \multicolumn{8}{|l|}{ Meat products } \\
\hline Press ham & 70 & 45 & 47 & 14 & 35 & 43 & 254 \\
\hline Sausage & 37 & 37 & 33 & 11 & 35 & 24 & 177 \\
\hline Ground meat & 3 & 18 & 13 & 5 & 18 & 24 & 81 \\
\hline \multicolumn{8}{|l|}{ Milk products } \\
\hline Processed cheese & 0 & 3 & 7 & 0 & 12 & 9 & 31 \\
\hline Total & 110 & 103 & 100 & 30 & 100 & 100 & 543 \\
\hline
\end{tabular}


(Promega, USA) at $100 \mathrm{~V}$ and a running time of $35 \mathrm{~min}$, stained with SYBR Safe DNA gel stain (Invitrogen, USA) and photographed using a Molecular Imager Gel Doc XR+ Imaging system (Bio-Rad, USA). A 100 bp ladder (Bioneer, Korea) consisting of DNA fragments ranging from 100-3,000 bp was used as marker.

\section{Results and Discussion}

The multiplex PCR analysis very quickly discriminated GMOs in a cost-saving and less time-consuming way. In addition, it is flexible because it is carried out on the same tube in the same run (Forte et al., 2005). Primer set for screening GMOs in food samples have been reported using conventional PCR (Chung et al., 2004; Kuribara et al., 2002). The present study used a one-step multiplex PCR analysis to determine the presence of GMOs in 543 processed livestock products such as press hams, sausages, processed ground meats, and processed cheeses obtained from commercial markets in two urban centers in Korea during 2005-2010. The single step involved the genomic DNA extraction and amplification of endogenous sequences of soy (lectin gene) and maize (zein gene), as well as GMO-specific sequences, represented by $35 \mathrm{~S}$ promoter and tNOS, which resolved bands of 201, 199, 101 , and $151 \mathrm{bp}$, respectively.

The analyzed samples mostly yielded a sufficient amount of DNA ( $>50 \mathrm{ng}$ ), with the exception of 12 processed cheese samples, in which the DNA concentration was $<50 \mathrm{ng}$. Among the 543 samples, only one sausage sample collected in 2008 was positive for one introduced 151 bp genetic element harboring tNOS gene (Table 3, Fig. 1). A $199 \mathrm{bp}$ fragment of maize endogenous gene was also amplified in this sample (Fig. 1). However, we assume that this could be false positive based on the results from further test of four other sausage samples of the same brand. No indication was also found for GM crops in the package of the sausage. PCR-based GMO tests can be categorized into four levels of specificity: screening methods, gene-specific methods, construct-specific methods, and event-specific methods. The screening test is the least specific, targeting DNA elements such as promoters and terminators that are present in many different GMOs (Miraglia et al., 2004). There are some limitations of this study, and one of them was that we used only the screening method to detect GMOs in this study.

Table 2. Primers used for detection of GMOs and endogenous genes of soybean and maize

\begin{tabular}{|c|c|c|c|c|c|}
\hline Primer & Orientation & Sequence $\left(5^{\prime} \rightarrow 3^{\prime}\right)$ & Target & $\begin{array}{l}\text { Amplicon } \\
\text { (bp) }\end{array}$ & References \\
\hline N-Lec-1 & Upstream primer & TGG GAC AAA GAA ACC GGT AG & \multirow{2}{*}{$\begin{array}{l}\text { Soybean endogenous } \\
\text { gene }\end{array}$} & \multirow{2}{*}{$201 \mathrm{bp}$} & \multirow{2}{*}{ Chung et al. (2004) } \\
\hline N-Lec-2 & Downstream primer & GTC AAA CTC AAC AGC GAC GA & & & \\
\hline N-Zein-1 & Upstream primer & TTT CTG CAA GTG CTG CTA CG & \multirow{2}{*}{$\begin{array}{l}\text { Maize endogenous } \\
\text { gene }\end{array}$} & \multirow{2}{*}{199 bp } & \multirow{2}{*}{ Chung et al. (2004) } \\
\hline N-Zein-2 & Downstream primer & AGG GCT GAT GAT TGT TGG AG & & & \\
\hline P35S 1-5, & Upstream primer & ATT CAT GTG ATA TCT CCA CTG ACG T & \multirow{2}{*}{$\begin{array}{l}\text { Soybean and maize } \\
\text { modified gene (p35S) }\end{array}$} & \multirow{2}{*}{$101 \mathrm{bp}$} & \multirow{2}{*}{$\begin{array}{l}\text { Kuribara et al. } \\
(2002)\end{array}$} \\
\hline P35S 1-3' & Downstream primer & ССТ СТC CAA ATG AAA TGA ACT TCC T & & & \\
\hline tNOS 2-5 & Upstream primer & GTC TTG CGA TGA TTA TCA TAT AAT TTC TG & \multirow{2}{*}{$\begin{array}{l}\text { Soybean and maize } \\
\text { modified gene (tNOS) }\end{array}$} & \multirow{2}{*}{$151 \mathrm{bp}$} & \multirow{2}{*}{$\begin{array}{l}\text { Kuribara et al. } \\
(2002)\end{array}$} \\
\hline tNOS 2-3, & Downstream primer & CGC TAT ATT TTG TTT TCT ATC GCG T & & & \\
\hline
\end{tabular}

Table 3. The number of genetically modified genes and endogenous genes detected by multiplex PCR in samples of livestock products

\begin{tabular}{|c|c|c|c|c|c|c|c|c|}
\hline \multirow[b]{2}{*}{ Year } & \multicolumn{4}{|c|}{ No. of GM detected } & \multicolumn{4}{|c|}{ No. of amplifications for endogenous gene } \\
\hline & $\begin{array}{l}\text { Press } \\
\text { ham }\end{array}$ & Sausage & $\begin{array}{c}\text { Ground } \\
\text { meat }\end{array}$ & $\begin{array}{c}\text { Processed } \\
\text { cheese }\end{array}$ & Press ham & Sausage & $\begin{array}{c}\text { Ground } \\
\text { meat }\end{array}$ & $\begin{array}{c}\text { Processed } \\
\text { cheese }\end{array}$ \\
\hline 2005 & 0 & 0 & 0 & $\mathrm{NT}^{1)}$ & 47 & 27 & 2 & NT \\
\hline 2006 & 0 & 0 & 0 & 0 & 44 & 37 & 18 & 2 \\
\hline 2007 & 0 & 0 & 0 & 0 & 45 & 32 & 12 & 6 \\
\hline 2008 & 0 & 0 & 0 & NT & 13 & 11 & 5 & NT \\
\hline 2009 & 0 & 0 & 0 & 0 & 32 & 33 & 17 & 2 \\
\hline 2010 & 0 & 0 & 0 & 0 & 42 & 23 & 24 & 3 \\
\hline Subtotal/Tested & $0 / 254$ & $0 / 177$ & $0 / 81$ & $0 / 31$ & $223 / 254(87.8)$ & $163 / 177(92.1)$ & $78 / 81(96.3)$ & $13 / 31(41.9)$ \\
\hline Total/All tested (\%) & \multicolumn{4}{|c|}{$0 / 543(0.0)$} & \multicolumn{4}{|c|}{$477 / 543(87.8)$} \\
\hline
\end{tabular}

1) Not tested 


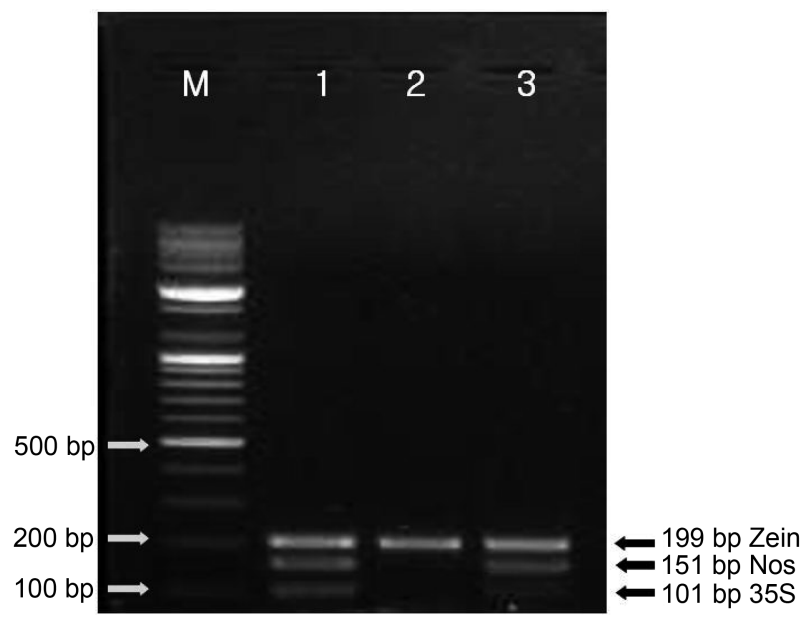

Fig. 1. Agarose gel electrophoresis of PCR products amplified from maize DNAs using p35S and tNOS primer pairs. M, 100 bp DNA marker; Lane 1, Positive control for genetically modified maize; Lane 2, Sausage sample added with maize starch; Lane 3, Sausage sample with false positive reaction. Arrows indicate the expected PCR amplification products.

Therefore, in the future, more specific methods should be established and employed to detect the event-specific GM gene for positive reaction samples by screening tests in processed livestock products.

DNAs from all extractions in this study were also checked for their endogenous genes and GM genes by agarose gel electrophoresis. Table 3 summarizes the number of amplified GM and endogenous genes for all 543 samples. Four hundred seventy seven samples $(87.8 \%)$ were amplified for maize or/and soybean endogenous genes. These samples resolved bands of approximately 199 and 201 bp for zein and lectin genes, respectively. In general, it is difficult to obtain significant amounts of amplifiable DNA as heat treatment, enzymatic activities, or acidic $\mathrm{pH}$ lead to fragmentation and other modifications of DNA (Hupfer et al., 1998; Wurz et al., 1999). In this study, ground meat samples yielded the most amplified samples for lectin and zein genes $(96.3 \%$ of samples), followed by sausage samples $(92.1 \%)$ and press ham samples $(87.8 \%)$. In contrast, thirteen $(41.9 \%)$ of 31 processed cheese resulted in amplification for lectin or/ and zein genes, and 12 of 31 samples had a low DNA quality with concentration of $<50 \mathrm{ng}$. This could be expected because of the highly fermented characteristics of cheese, making the detection of soy or maize endogenous gene difficult. This result is similar with other reports of the lack of extracted DNA from highly fermented products such as soy margarine, soy sauce, and soy and maize oil (Abdullah et al., 2006; Greiner et al., 2005). In addi- tion, since milk products include factors such as proteinase that inhibits the PCR reaction (Powell et al., 1994; Rossen et al., 1992; Wernars et al., 1991), no amplification was presently apparent despite sufficient DNA concentration for PCR. Hence, other technical methods are needed for better efficiency of DNA extraction from fermented dairy products such as cheese.

In conclusion, our results demonstrate the absence of GM soya or/and maze of livestock products in Korean market during 2005-2010. In addition, the one-step multiplex PCR using previously constructed primer sets appears to be useful as a screening method for the detection of GMOs in processed livestock products. However, further studies are needed to detect the event-specific GM gene for positive reaction samples by screening tests in processed livestock products.

\section{Acknowledgement}

This work was supported by National Veterinary Research \& Quarantine Service, Ministry for Food, Agriculture, Forestry and Fisheries, Republic of Korea.

\section{References}

1. Abdullah, T., Radu, S., Hassan, Z., and Hashim, J. (2006) Detection of genetically modified soy in processed foods sold commercially in Malaysia by PCR-based method. Food Chem. 98, 575-579.

2. Chung, M., Jung, S., Kim, K., Kim, S., Song, S., and Cho, N. (2004) Development and application of polymerase chain reaction methods for detection of the GMO (genetically modified organism) in meat products. Korea J. Vet. Publ. Hlth. 28, 97-107.

3. Food and Marketing Bureau (2000) Ministry of Agriculture, Forestry and Fisheries of Japan, Tokyo, Japan. Notification No. 1775.

4. Forte, V., Di Pinto, A., Martino, C., Tantillo, G., Grasso, G., and Schena, F. (2005) A general multiplex-PCR assay for the general detection of genetically modified soya and maize. Food Cont. 16, 535-539.

5. Gachet, E., Martin, G., Vigneau, F., and Meyer, G. (1998) Detection of genetically modified organisms (GMOs) by PCR: a brief review of methodologies available. Trends Food Sci. Tech. 9, 380-388.

6. Greiner, R., Konietzny, U., and Villavicencio, A. L. C. H. (2005) Qualitative and quantitative detection of genetically modified maize and soy in processed foods sold commercially in Brazil by PCR-based methods. Food Cont. 16, 753759.

7. Holst-Jensen, A., RØnning, S., LØvseth, A., and Berdal, K. (2003) PCR technology for screening and quantification of 
genetically modified organisms (GMOs). Anal. Bioanal. Chem. 375, 985-993.

8. Hupfer, C., Hotzel, H., Sachse, K., and Engel, K. (1998) Detection of the genetic modification in heat-treated products of Bt maize by polymerase chain reaction. Z. Lebensm. Unters. F A. 206, 203-207.

9. Hurst, C., Knight, A., and Bruce, I. (1999) PCR detection of genetically modified soya and maize in foodstuffs. Mol. Breeding 5, 579-586.

10. Hwang, S., Lee, C., Nam, Y., Kim, S., Oh, D., and Kim, Y. (2003a) Comparative study of DNA fragment according to steps of genetically modified soybean processed food. $J$. Food Hyg. Safety 18, 211-217.

11. Hwang, Y., Kim, H., Kang, T., Lee, J., Lee, I., Shin, D., Kim, S., and Kim, K. (2003b) Physio-ecological characteristics of wild soybeans (Glycine soja) collected throughout Korea and their response to glyphosate. Korea J. Weed Sci. 23, 153159.

12. KFDA (2000) Labeling standards for genetically modified foods. KFDA Notification, Korea. No. 2000-43.

13. Kim, C., Yi, H., Park, S., Yeon, J., Kim, D., Kim, D., Lee, K., Lee, T., Paek, I., and Yoon, W. (2006) Monitoring the occurrence of genetically modified soybean and maize around cultivated fields and at a grain receiving port in Korea. J. Plant Biol. 49, 218-223.

14. KOSIS (2005) Statistical Database. Available from: http:// www.nso.go.kr/eng/searchable/kosis-list.html.

15. Kuribara, H., Shindo, Y., Matsuoka, T., Takubo, K., Futo, S., Aoki, N., Hirao, T., Akiyama, H., Goda, Y., and Toyada, M. (2002) Novel reference molecules for quantitation of genetically modified maize and soybean. J. AOAC Int. 85, 10771089.

16. Lee, C., Kim, Y., Hwang, S., and Kang, S. (2004a) Changes in DNA fragments in BT11 corn caused by processing conditions and their monitoring. Korea J. Food Sci. Technol. 36, 299-305.

17. Lee, S., Park, Y., Kim, J., Park, K., and Kim, Y. (2004b) Qualitative PCR method for detection of genetically modified maize lines NK603 and TC1507. Agric. Chem. Biotechnol. 47, 185-188.

18. Lin, H., Chiang, J., and Shih, D. (2001) Detection of genetically modified soybeans by PCR method and immunoassay kits. J. Food Drug Anal. 9, 160-166.

19. MAF (2000) Guideline for labeling of genetically modified agricultural products. Korea MAF notification. No. 2000-31.

20. Matsuoka, T., Kuribara, H., Akiyama, H., Miura, H., Goda, Y., Kusakabe, Y., Isshiki, K., Toyoda, M., and Hino, A. (2001)
A multiplex PCR method of detecting recombinant DNAs from five lines of genetically modified maize. J. Food Hyg. Soc. Jpn. 42, 24-32.

21. Meyer, R. (1995) Nachweis gentechnologisch veranderter Pflanzen mittels der Polymerase Kettenreaktion (PCR) am Beispiel derFlavr Savr TM-Tomate. Z. Lebensm. Unters. F A. 201, 583-586.

22. Meyer, R., Chardonnens, F., Hubner, P., and Luthy, J. (1996) Polymerase chain reaction (PCR) in the quality and safety assurance of food: detection of soya in processed meat products. Z. Lebensm. Unters. F A. 203, 339-344.

23. Miraglia, M., Berdal, K., Brera, C., Corbisier, P., HolstJensen, A., Kok, E., Marvin, H., Schimmel, H., Rentsch, J., and Van Rie, J. (2004) Detection and traceability of genetically modified organisms in the food production chain. Food Chem. Toxicol. 42, 1157-1180.

24. Phillips, P. and McNeill, H. (2000) A survey of national labeling policies for GM foods. Ag. Bio. Forum. 3, 219-224.

25. Powell, H., Gooding, C., Garrett, S., Lund, B., and McKee, R. (1994) Proteinase inhibition of the detection of Listeria monocytogenes in milk using the polymerase chain reaction. Lett. Appl. Microbiol. 18, 59-61.

26. Regulation (EC). (2003) No 1829/2003 on genetically modified food and feed. Official J. European Union 268, 10.

27. Rho, J., Lee, T., Jung, S., Park, Y., and Kim, Y. (2004) Qualitative and quantitative PCR methods for detection of three lines of genetically modified potatoes. J. Agric. Food Chem. 52, 3269-3274.

28. Rossen, L., Nørskov, P., Holmstrøm, K., and Rasmussen, O. F. (1992) Inhibition of PCR by components of food samples, microbial diagnostic assays and DNA-extraction solutions. Int. J. Food Microbiol. 17, 37-45.

29. Tengel, C., Schussler, P., Setzke, E., Balles, J., and SprengerHaussels, M. (2001) PCR-based detection of genetically modified soybean and maize in raw and highly processed foodstuffs. Biotech. 31, 426-429.

30. Wernars, K., Heuvelman, C., Chakraborty, T., and Notermans, S. (1991) Use of the polymerase chain reaction for direct detection of Listeria monocytogenes in soft cheese. $J$. Appl. Microbiol. 70, 121-126.

31. Wurz, A., Bluth, A., Zeltz, P., Pfeifer, C., and Willmund, R. (1999) Quantitative analysis of genetically modified organisms (GMO) in processed food by PCR-based methods. Food Cont. 10, 385-389.

(Received 2011.5.27/Revised 2011.9.9/Accepted 2011.9.15) 